\title{
Biofilm Detection on Catheter Associated Uropathogenic Bacteriuria among Fistula Patients Attending National Obstetric Fistula Centre Ningi, Bauchi State, Nigeria
}

\author{
Ngozi V. Uzuegbunam, Faruk A. Umar, and Bassey Enya Bassey
}

\section{ABSTRACT}

Background: Biofilm production caused by bacteria plays a vital role in
catheter associated urinary tract infection (UTI) or bacteriuria being
responsible for persistence and recurrent infection. Biofilms forming
bacteria are difficult to eradicate due to antimicrobial resistance to the
commony used antibiotic. Biofilms are currently estimated to be
responsible for over $65 \%$ of nosocomial infections and $80 \%$ of microbial
infections. This study aimed to perform biofilm detection on uropathogenic
bacterial isolates among fistula patients attending National Obstetric
Fistula centre Ningi and investigate the antimicrobial susceptibility pattern.

Methods: A total of 217 strains of significant bacteriuria were isolated from vesico vaginal fistula (VVF) patients. A cross sectional study was conducted at the hospital. The urine samples were collected and cultured on CLED and blood agar media while confirmation was done using their biochemical reaction. The detection of biofilms formation on the isolates was performed using tube adherence and Congo red agar method. Antimicrobial susceptibility testing was carried out by disc diffusion method on Muller Hinton agar.

Results: Out of 217 significant bacteriuria isolated, 38 strains produced biofilms;28 strains tested positive on tube adherence method while 15 strains were positive on Congo red agar method. Bacteria that produced biofim showed multiple drug resistance compared to the platonic bacterial cells. All the biofilm producers showed $100 \%$ resistant to septrin, ampiclox, gentamycin and amoxicillin. There was no significant value between tube adherence and Congo red agar method with $P$ value $>0.05$.

Conclusion: Biofilm detection should form part of routine testing while antimicrobial susceptibility testing is paramount on better choice of antibiotic therapy for proper management to reduce economic lost, treatment failure and drug resistance.

Keywords: Biofilm, Uropathogenic bacteriuria, vesico vaginal fistula, Antibiotic Resistance.

\section{INTRODUCTION}

Biofilm formation is a major concern in nosocomial infections because it protects microorganisms from opsonophagocytosis and antibiotics, leading to chronic infection and sepsis [1]. These qualities have converged to make catheter-associated bacteriuria a significant burden on our current health care system [2]. Whenever biofilmassociated infections occur, they are difficult to be treated by conventional procedures [2]. Biofilm infections are generally associated with the use of catheters and other medical devices [3]. The Biofilm consists of layers of cell clusters embedded in a matrix of extracellular polysaccharide called polysaccharide intracellular adhesion (PIA), which are made of b-1,6-N-acetylglycosamine and synthesized by $\mathrm{N}$ -
Submitted : March 1, 2021

Published : April 26, 2021

ISSN: $2593-8339$

DOI: 10.24018 /ejmed.2021.3.2.803

\section{Ngozi V. Uzuegbunam}

Medical laboratory services, National Obstetric Fistula Centre, Ningi, Bauchi, Nigeria.

(e-mail: ngverau@gmail.com)

Faruk A. Umar

Department of Microbiology, Abubakar Tafawa Belewa University, Bauchi State, Nigeria.

(e-mail: faruk63@yahoo.com)

Bassey Enya Bassey*

World Health Organization (WHO) Nigeria Country Office, Garki, Abuja, Nigeria.

(e-mail: bassey69@yahoo.com)

*Corresponding Author acetylglucosaminyl transferase. This PIA is involved in cellcell adhesion and is essential for biofilm production by CNS, which is observed in most clinical strains of bacteria. Biofilms are ubiquitous and it occur as a result of one or multiple bacterial species forming complex structure [4]. Biofilm are estimated to be responsible for over $80 \%$ of microbial infection leading to persistence infection and relapses. Biofilms formation by uropathogenic bacteriuria is considered a pathogenicity trait. Biofilm helps to promotes colonization leading to high rates of urinary tract infection (UTI), hence making the infection the infections difficult to treat due to multiple drug resistance. Urinary tract is divided into two, the upper and lower urinary tract which comprises of ureter, kidney, urethra, and bladder [5]. Bacteria infects through ascending route in $90 \%$ of urinary tract infection, 
mainly from feacal flora of the host. Escherichia coli are the major etiologic agents of UTI [6]. A total of 150 million people is affected by UTI worldwide. The incidence is higher in women estimated to be about $40-50 \%$ of adult women experiencing it once in lifetime [7]. Catheterization of the urinary tract increases the risk of bacteriuria up to $10 \%$ a day and the majority of patients with indwelling urinary catheter for 30 days or longer develop bacteriuria [8], [9]. Recent efforts to prevent UTI have focused mainly on preventing bacterial entry to the urinary tract or eradicating bacteriuria after its onset have been unsuccessful.

Fistula is an abnormal opening between organs and other structures in the body. It can occur at any organs of the body but most common in the pelvic region. Vesico vaginal fistula is an abnormal opening between the bladder and the vagina which lead to involuntary discharge of urine into the vaginal vault [5]. It is a major concern of complication of gynecological and obstetric procedures in developing world. The diagnosis of fistula has been based on clinical methods and dye testing, but the continuous wetness, odour, discomfort, and bacterial infection cause serious social problems and urinary tract infection [10], [11]. The major challenges of VVF are common in developing countries especially in African where about 30,000-130,000 new cases develop each year [10]. Again, high prevalence of early marriage, childbearing, low illiteracy rate, female genital mutilation, poor antenatal care among patients in the northern Nigeria are the major factor resulting to VVF. In addition, lack of access to emergency obstetric services, obstructed labour, multiple rape, inadequately developed social and economic infrastructures are all more common in developing countries [12]. The most common cause of VVF is obstructed labour which is because of a massive field injury caused by the foetal. In most developing world, $90 \%$ of the injury is caused by obstructed labour [13].

The diagnosis of Biofilm forming bacterial depends on signs, symptoms, and multiple antibiotic resistances in the case of symptomatic infection and no sign due to asymptomatic infection. The urine analysis is performed, if indicated a urine culture will be done and the bacterial isolates will be subjected to either tissue culture plate, tube adherence or Congo red agar methods [14]. The aim of this study is to determine the Biofilm forming bacteria of catheter associated bacteriuria among fistula patients in National obstetric fistula centre Ningi, Bauchi State. The objectives were to investigate the antimicrobial susceptibility pattern and correlate the antibiotic resistance on biofilm forming bacterial isolates.

\section{MATERIALS AND METHODS}

\section{A. Study Area}

The research was done in National Obstetric Fistula Centre Ningi of Bauchi State. A cross sectional study was carried out between January and July 2018. The urine samples were collected, examined, and processed after obtaining informed consent from the patients admitted into the hospital. Ethical approval was given by the management group of the ethical committee of National Obstetric Fistula Centre Ningi, Bauchi State. The approval was that the confidentiality of the patients must be maintained, and good laboratory practice/quality control must be ensured for the purpose of research only. This is in agreement with the National Code for Health Research Ethics of Nigeria.

Clean catch mid-stream urine was collected from the patients at the pre- and post-operative unit using sterile syringe. The urine sample was investigated using standard microbiological method [5], [15], [16]. The urine was cultured on Cysteine Lactose Electrolyte Deficient agar (CLED) and Blood agar media [5], [17]. It was incubated aerobically at $37{ }^{\circ} \mathrm{C}$ for $24 \mathrm{~h}$. The biofilms detection was carried out on Tube adherence and Congo red agar methods. The suspension of the test strains was incubated in borosilicate tubes which contained brain heart infusion broth aerobically at a temperature of $35^{\circ} \mathrm{C}$ for a period of 2 days, supernatant discarded and stained with $0.1 \%$ safaranin. A positive result was defined as the presence of a layer of the stained material which adhered to the inner wall of the tubes down to the bottom while exclusive observation of a stained ring only at the interface was considered as negative [18], [19]. The bacterial isolates were inoculated on the solid medium containing brain heart infusion broth supplemented with 5\% sucrose and incubated aerobically for 24-48 hours at $37{ }^{\circ} \mathrm{C}$. The positive result showered black colonies with a dry crystalline, weak biofilm producer usually remain pink, with occasional darkening at the centre of the colonies while no colour change indicates a negative result [4], [19], [20]. Both experiments are performed in triplicates. Antimicrobial susceptibility testing was performed on Muller Hinton agar (Oxoid, England) using disc diffusion method and interpreted according to CLSI [5], [19], [21]. Data were analyzed and interpreted using SPSS version 20 software and variables were determined using chi-square. All statistical tests were considered significant at $\mathrm{P}<0.05$.

\section{RESULT}

\section{A. Distribution of Bacteriuria among Fistula Patients from the Analysis of Their Urine Samples in Relation to Age Group}

Table I shows the distribution of bacteriuria among fistula patients from the analysis of their samples in relation to age group. It showed that patients above $>45$ years had the highest percentage of significant bacteriuria $28(87.5 \%), 16-25$ years with $85(81 \%)$, the least were aged $5-15$ years $(54.5 \%)$ while the age range of $16-25$ years with $85(81 \%)$ had the highest number of significant bacteriuria.

TABLE I: DISTRIBUTION OF BACTERIURIA AMONG FISTULA PATIENTS FROM THE ANALYSIS OF THEIR URINE SAMPLES IN RELATION TO AGE

\begin{tabular}{|c|c|c|c|c|c|}
\hline \multicolumn{6}{|c|}{ GROUP } \\
\hline $\begin{array}{l}\text { Age } \\
\text { (year) }\end{array}$ & $\begin{array}{c}\text { Significan } \\
\mathrm{t} \\
\text { Bacteriuri } \\
\mathrm{a}\end{array}$ & $\begin{array}{l}\text { Non- } \\
\text { Significant } \\
\text { Bacteriuria }\end{array}$ & $\begin{array}{c}\text { Total } \\
\text { Number } \\
\text { of } \\
\text { Patients } \\
\text { Examined }\end{array}$ & $\begin{array}{c}\% \\
\text { Positive }\end{array}$ & $\begin{array}{c}\% \\
\text { Negativ } \\
\mathrm{e}\end{array}$ \\
\hline $5-15$ & 6 & 5 & 11 & 54.5 & 45.5 \\
\hline $16-25$ & 85 & 20 & 105 & 81 & 19 \\
\hline $26-35$ & 54 & 34 & 88 & 61.4 & 38.6 \\
\hline $35-45$ & 44 & 25 & 69 & 61.1 & 36.2 \\
\hline$>45$ & 28 & 4 & 32 & 87.5 & 12.5 \\
\hline Total & 217 & 88 & 305 & 71.1 & 28.9 \\
\hline
\end{tabular}

$\mathrm{X}^{2}(2)=0.683, \mathrm{P}>0.05$ 


\section{B. Distribution of Bacterial Isolates from Biofilm} Production in Tube Adherence (TA) and Congo Red Agar (CRA) Methods

Table II shows the distribution of 217 bacterial isolates for biofilm formation on tube adherence and Congo red agar methods. The Tube adherence method had the highest number of biofilm production $23(71.4 \%)$ than the Congo red agar method 15 (39.2\%). There was no significant difference between the two methods $\mathrm{p}>0.05$.

\section{Antimicrobial Susceptibility Profile of Isolated Bacteria that Produce Biofilm}

Table III shows those bacteria that produce biofilms had complete resistance to these listed antibiotics, septrin, sparfloxacin, Amoxacillin and gentamicin while E. coli was highly sensitive to streptomycin.

TABLE II: DISTRIBUTION OF BACTERIAL ISOLATES FOR BIOFILM PRODUCTION IN TUBE ADHERENCE (TA) AND CONGO RED AGAR (CRA) METHODS

\begin{tabular}{|c|c|c|c|c|}
\hline \multirow{3}{*}{ Bacteria Isolated } & Tube & Congo & $\%$ Biofilm & $\%$ Biofilm \\
\hline & Adherence & Red Agar & Formation & Formation \\
\hline & Positive & Positive & For TA & For CRA \\
\hline Escherichia coli $\mathrm{n}=85$ & 11 & 9 & (12.9) & $(10.6)$ \\
\hline Staphylococcus aureus $\mathrm{n}=14$ & 4 & 2 & $(28.6)$ & (14.3) \\
\hline Klebsiella pneumonae $\mathrm{n}=29$ & 3 & 2 & $(10.3)$ & $(6.9)$ \\
\hline Coagulase Negative $S \mathrm{n}=21$ & 3 & 1 & (14.3) & $(4.8)$ \\
\hline Proteus $\mathrm{spp} \mathrm{n}=38$ & 0 & 0 & $(0.0)$ & $(0.0)$ \\
\hline Pseudomonas spp $n=18$ & 2 & 1 & $(5.3)$ & (2.6) \\
\hline Citobacter spp $\mathrm{n}=5$ & 0 & 0 & $(0.0)$ & $(0.0)$ \\
\hline Enterobacter $\mathrm{spp} \mathrm{n}=4$ & 0 & 0 & $(0.0)$ & $(0.0)$ \\
\hline Serriatia $\operatorname{spp} \mathrm{n}=3$ & 0 & 0 & $(0.0)$ & $(0.0)$ \\
\hline Total $\%$ & 23 & 15 & (71.4) & $(39.2)$ \\
\hline
\end{tabular}

$\mathrm{X}^{2}(4)=0.749, \mathrm{P}>0.05$

TABLE III: ANTIMICROBIAL SUSCEPTIBILITY PROFILE OF ISOLATED BACTERIA THAT PRODUCE BIOFILM

\begin{tabular}{|c|c|c|c|c|c|c|c|c|c|c|c|c|c|}
\hline \multirow{2}{*}{ Bacteria Isolated } & & \multicolumn{12}{|c|}{ Antibiotics Tested } \\
\hline & & SXT & $\mathrm{CH}$ & SP & CPX & AM & $\mathrm{CN}$ & PEF & OFX & $\mathrm{S}$ & $\mathrm{AU}$ & $\mathrm{R}$ & $\mathrm{Z}$ \\
\hline E coli & $\mathrm{S}$ & $0(0)$ & $0(0)$ & $0(0)$ & $1(5)$ & $0(0)$ & $0(0)$ & $1(5)$ & $2(10)$ & $4(20)$ & $1(5)$ & $0(0)$ & $0(0)$ \\
\hline \multirow[t]{2}{*}{$\mathrm{n}=20$} & I & $0(0)$ & $0(0)$ & $0(0)$ & $9(45)$ & $0(0)$ & $0(0)$ & $1(5)$ & $2(10)$ & $3(15)$ & $4(20)$ & $0(0)$ & $0(0)$ \\
\hline & $\mathrm{R}$ & $20(100)$ & $20(100)$ & $20(100)$ & $10(50)$ & $20(100)$ & $20(100)$ & $18(90)$ & $16(80)$ & $13(65)$ & $15(75)$ & $20(100)$ & $20(100)$ \\
\hline \multirow{3}{*}{$\begin{array}{l}\text { Klebsiella spp } \\
\mathrm{n}=5\end{array}$} & $\mathrm{~S}$ & $0(0)$ & $0(0)$ & $0(0)$ & $0(0)$ & $0(0)$ & $0(0)$ & $1(20)$ & $0(0)$ & $1(20)$ & $1(20)$ & $0(0)$ & $0(0)$ \\
\hline & I & $0(0)$ & $0(0)$ & $0(0)$ & $2(40)$ & $0((0)$ & $0(0)$ & $0(0)$ & $0(0)$ & $1(20)$ & $0(0)$ & $0(0)$ & $0(0)$ \\
\hline & $\mathrm{R}$ & $5(100)$ & $5(100)$ & $4(100)$ & $3(60)$ & $5(100)$ & $5(100)$ & $4(80)$ & $5(100)$ & $3(60)$ & $4(80)$ & $5(100)$ & $5(100)$ \\
\hline \multirow{3}{*}{$\begin{array}{l}\text { Pseudomonas spp } \\
n=3\end{array}$} & $\mathrm{~S}$ & $0(0)$ & $0(100)$ & $0(0)$ & 1(33.3) & $0(0)$ & $0(0)$ & $1(33.3)$ & $1(33.3)$ & $1(33.3)$ & $0(0)$ & $0(0)$ & $0(0)$ \\
\hline & I & $0(0)$ & $0(0)$ & $0(0)$ & 1(33.3) & $0(0)$ & $0(0)$ & 1(33.3) & $0(0)$ & $1(33.3)$ & $1(33.3)$ & $0(0)$ & $0(0)$ \\
\hline & $\mathrm{R}$ & $3(100)$ & $3(100)$ & $3(100)$ & 1(33.3) & $3(100)$ & $3(100)$ & 1(33.3) & $2(66.6)$ & $1(33.3)$ & $2(66.6)$ & $3(100)$ & $3(100)$ \\
\hline CONS & $\mathrm{S}$ & $0(0)$ & $0(0)$ & $0(0)$ & $1(25)$ & $0(0)$ & $0(0)$ & $1(25)$ & $1(25)$ & $1(25)$ & $0(0)$ & $2(50)$ & $1(25)$ \\
\hline \multirow[t]{2}{*}{$\mathrm{n}=4$} & I & $0(0)$ & $0(0)$ & $0(0)$ & $0(0)$ & $0(0)$ & $0(0)$ & $1(25)$ & $1(25)$ & $0(0)$ & $0(0)$ & $0(0)$ & $1(25)$ \\
\hline & $\mathrm{R}$ & $4(100)$ & $4(100)$ & $4(100)$ & $3(75)$ & $4(100)$ & $4(100)$ & $2(50)$ & $2(50)$ & $3(75)$ & $4(100)$ & $2(50)$ & $2(50)$ \\
\hline \multirow{3}{*}{$\begin{array}{c}\text { Staphylococcus spp } \\
n=6\end{array}$} & $\mathrm{~S}$ & $0(0)$ & $0(0)$ & $0(0)$ & $2(33.3)$ & $0(0)$ & $0(0)$ & $0(0)$ & $0(0)$ & $2(33.3)$ & $0(0)$ & $1(16.6)$ & $1(16.6)$ \\
\hline & I & $0(0)$ & $0(0)$ & $0(0)$ & $1(16.6)$ & $0(0)$ & $0(0)$ & $0(0)$ & $0(0)$ & $2(33.3)$ & $0(0)$ & $1(16.6)$ & 1(16.6) \\
\hline & $\mathrm{R}$ & $6(100)$ & $6(100)$ & $6(100)$ & $3(50)$ & $6(100)$ & $6(100)$ & $6(100)$ & $6(100)$ & $2(33.3)$ & $6(100)$ & 1(16.6) & $4(66.6)$ \\
\hline
\end{tabular}

KEY: S=Susceptible, I=Intermediate, R=Resistant, CoNS=Coagulase negative staphylococcus, SXT=Septrin $(30 \mu \mathrm{g})$ APX=Ampiclox $(30 \mu \mathrm{g})$ $\mathrm{R}=$ Rocephin $(20 \mu \mathrm{g}) \mathrm{CPX}=$ Ciprofloxacin $(10 \mu \mathrm{g})$.

$\mathrm{AM}=$ Amoxicillin $(30 \mu \mathrm{g}), \mathrm{CN}=$ Gentamicin $(10 \mu \mathrm{g}), \mathrm{PEF}=$ Pefloxacin $(30 \mu \mathrm{g}), \mathrm{S}=$ Streptomycin $(30 \mu \mathrm{g}), \mathrm{Z}=\mathrm{Zinacef}(20 \mu \mathrm{g}), \mathrm{CH}=\mathrm{Chloramphenicol}(30 \mu \mathrm{g})$, $\mathrm{SP}=$ Sparfloxacin $(10 \mu \mathrm{g})$.

\section{Clinical Presentation of Fistula Patient Admitted into NOFC, Ningi-Bauchi State}

Table IV shows that the common clinical features presented by fistula patients were irritative voiding symptom $79(26 \%)$, hematuria $55(18 \%)$ and the least is suprapubic pain $10(3 \%)$.

TABLE IV: Clinical PRESENTAtion OF Fistula Patient AdMitTed INTO NOFC, NINGI-BAUCHI STATE

\begin{tabular}{cccc}
\multicolumn{4}{c}{ INTO NOFC, NINGI-BAUCHI STATE } \\
\hline $\begin{array}{c}\text { Clinical } \\
\text { Presentation }\end{array}$ & $\begin{array}{c}\text { Positive } \\
(\%)\end{array}$ & $\begin{array}{c}\text { Negative } \\
(\%)\end{array}$ & $\begin{array}{c}\text { Total number of patients } \\
\text { examined }(\%)\end{array}$ \\
\hline Suprapubic pain & $10(3)$ & $295(97)$ & $305(100)$ \\
Nocturia & $42(14)$ & $263(86)$ & $305(100)$ \\
Hematuria & $55(18)$ & $250(82)$ & $305(100)$ \\
Irritative Voiding & $79(26)$ & $226(74)$ & $305(100)$ \\
symptom & $31(10)$ & $274(90)$ & $305(100)$ \\
Dysuria & & &
\end{tabular}

\section{DISCUSSION}

Biofilm forming bacteria is one of the key causes of persistence bacterial infection leading to antibiotic resistance treatment failure around the globe. Biofilm production promotes colonization and increase rate of uropathogenic bacteriuria especially on catheterized individuals. Infection caused by Biofilm producers are difficult to eradicate as they exhibit multiple antibiotic drug resistance [22], [23]. The prevalence of biofilm forming bacteriuria are $17.5 \%$ which is relatively low compare to non- biofilm forming bacteria. This study showered that 217 strain of bacterial isolates shows significant bacteriuria which could be due long duration of the incontinence of urine and stool among the patients. Table I shows that the majority of bacteria isolated were between the age group $16-25$ years with $85(81 \%)$ and $>45$ years with $28(87 \%)$, the least was on the age range of 5-15 years with 6 (54.5). This could be due to illiteracy, low personal hygiene among the productive age group with cultural belief of early 
marriage and hormonal changes, decline in the immune system of the older age especially with long duration of fistula which is in line with the study by [24]-[25]. The sociodemographic data of the fistula patients carried out by [5] indicated high rates of divorce which negates personal hygiene due to lack of support (financially and morally) from their spouse or family. In this study about $90 \%$ of the fistula patients are married with divorce rate of $10 \%$ divorce yet personal hygiene poses a great challenge. Table II shows that both methods are effective in detection of biofilm production and these finding suggest an association between biofilm production with persistence infection and antibiotic resistance. This is consistent with other researchers that biofilm-based infection is presented with multiple resistance of bacterial isolates to the commonly used antibiotic as well as resisting phagocytosis and other components of the body defence system [26], [27]. The common symptoms presented were irritative voiding syndrome, heamaturia, fever and supra pubic pain which are some of the sign and symptom of suspected urinary tract infection [24]. Table III indicates that all the biofilm forming bacteria showered multiple resistances to all the commonly used antibiotics and antibiotic rating was done according to CLSI 2014. This study indicates that gram negative biofilm forming bacteria isolated showered high level of multiple resistance to septrin $(100 \%)$, gentamicin (100\%), chlorophenicol (100\%), Ampiclox (100\%), Sparfloxacin (100\%) compared to non-biofilm forming bacteria [14]. Also, all the isolates were relatively sensitive to streptomycin (45\%) and ciprofloxacin (35\%) for those undergoing surgery for the first time while non-biofilm forming bacteria are highly susceptible to streptomycin with about $75 \%$ sensitive. This work agrees with the study carried out by [29] but in disagreement with the study performed by [4], [30] and [31]. The variability in antibiotic susceptibility pattern observed by different researchers may be as a result of geographical location from where those isolates were been obtained. The antibiotic resistances among biofilm producers were found higher than that of non-biofilm forming bacteria, $\mathrm{P}$ value $<0.05 \%$. Biofilm producing bacteria are responsible for many re infection and very difficult to eradicate. This gram-negative bacterium promotes colonization and may lead to increased UTI that may be difficult to treat as they exhibit multiple antibiotic resistances. This study is in accordance with work done by [23], [31], that $60 \%$ of the biofilm producers are highly resistance compare to its counterpart. Again, it was noticed that those biofilm producers that were resistance to commonly used antibiotic indicate slight susceptibility when more than one antibiotic was used and increase in time duration for the antibiotics. This study suggests that patients with biofilm producing bacteria need more concentration and longer duration of antibiotic as they have to reach the base of biofilm, the extracellular polymeric substance. Again, more research is needed to come out with standard concentration of antibiotic, time duration and more clinical trial for better result.

\section{REFERENCES}

[1] Martí, M., Trotonda, M. P., Tormo-Más, M. Á., Vergara-Irigaray, M., Cheung, A. L., Lasa, I. and Penadés, J. R. Extracellular proteases inhibit protein-dependent biofilm formation in Staphylococcus aureus. Microbes and infection, 2010; 12(1): 55-64.

[2] Ghellai Lotfi, Hassaine Hafida, Klouche Nihel, Khadir Abdelmonaim, Aissaoui Nadia, Nas Fatima and Zingg Walter. Detection of biofilm formation of a collection of fifty strains of Staphylococcus aureus isolated in Algeria at the University Hospital of Tlemcen. J. Bacteriology Res Vol. 6(1), pp. 1-6, February 2014, DOI: 10.5897/JBR2013.0122ISSN 2006-9871.

[3] Donlan RM. Biofilms and Device-Associated Infections. Emerging Infectious Diseases. 2001;7(2):277-281. doi:10.3201/eid0702.700277.

[4] Rashmi M. Karigoudar, Mahesh H. Karigoudar, Sanjay M. Wavare and Smita S. Mangalgi. Detection of Biofilm among uropathogenic Escherichia coli and its correlation with antibiotic resistance pattern, $J$ Lab Physicians, 2019; 11(1) 17-22.

[5] Uzuegbunam NV, Moshood AY, Faruk AU and Bassey EB. Catheterassociated bacteriuria among fistula patients attending national obstetric fistula centre Ningi Bauchi state, Nigeria. J of Med Lab Sci,2019;29(2):49-58.

[6] Kaper JB, Nataro JP, Mobley H.L. Pathogenic Escherichia coli, Nat Rev Microbiol, 2004;2:123-40.

[7] Tarchouna M, Ferjani A, Ben Selma W and Boukadida J. Distribution of uropathogenic virulence genes in Escherichia coli isolated from patients with UTI, Int j Infect Dis ;2013:7(6)134-139.

[8] Warren JW, Tenney JH, Hoopes JM, Muncie HL and Anthony WC. A prospective microbiologic study of bacteriuria in patients with chronic indwelling urethral catheters, J Infect Dis, 1982;146:719-23.

[9] Stamm, W. E. Catheter -associated urinary tract infections, Epidemiology, pathogenesis and prevention. Am J Med, 1991;91:655$71 \mathrm{~s}$.

[10] Wall LL. Obstetric vesicovaginal fistula as an international public health problem lancet, 2006; 368:1201-1209.

[11] Ibrahim T, Sadiq AU, Daniel SO. Characteristics of VVF patients as seen at the specialist hospital Sokoto, Nigeria. West African $J$ of Medicine, 2000; 19(1):59-63.

[12] Bhaha J. Rape epidemic fuels fistula cases in the democratic republic of congo conversation for better world Archived from the original. 28 August, 2010.

[13] Hilton P. Vesicovaginal fistulas in developing countries. International J of Gynaecology Obstetric,2003; 82: 285-295.

[14] Rashmi MK and Mahantesh BM. Characterization and antibiotic susceptibility pattern of coagulase negative staphylococci with special reference to methicillin resistance. Int $J$ Curr Microbiol App Sci, 2016;5:114-20.

[15] Cheesbrough, M. (2000). District Laboratory Practice in Tropical Countries. Part 2, Cambridge University Press.UK, pp 34-243.

[16] El-Naggar W, Hassan R, Barwa R, Shokralla S, Elgaml A. Molecular diagnosis of gram negative bacteria in urinary tract infections. Egyptian $J$ of Medical Microbiology, 2010; 19(1).

[17] Adeoye IS, Oladeinde O, Adeoye J. An assessment of asymptomatic bacteriuria among women with vesico- vaginal fistula in SouthEastern, Nigeria. Nepal J of Epidemiology, 2010; 1(2): 64 -69.

[18] Christensen, G. D., Simpson, W. A., Bisno, A. L. and Beachey, E. H. Adherence of slime producing strains of Staphylococcus epidermidis to smooth surfaces. Infectious Immunology, 1982; 37:318-26.

[19] Afrenish H, Javaid U, Fatima K, Maria O, Ali K, Muhammad I. Evaluation of different detection methods of biofilm in the clinical isolate. Brazilian J of Infectious Diseases, 2011; 15(4): 305-11.

[20] Freeman, J., Falkiner, F. R. and Keane, C. T. New method for detecting slime production by coagulase negative staphylococci,Journal Clinical Pathology, 1989; 42:872-874.

[21] Graham JC, Galloway A. The laboratory diagnosis of urinary tract infection. J Clinical Pathology, 2001; 54:911-919.

[22] Sevenan M, Pongiya U and Peedikavil NJ. Antimicrobial susceptibility pattern of Biofilm producing Escherichia coli of urinary tract infections, Curr Res Bacteriol, 2011;4:73-80.

[23] Saroj G, Vivek H, Sujala K.K, Reddy M. Correlation between Biofilm formation of uropathogenic Escherichia coli and its antibiotic resistance pattern, j Evol Med Dent Sci, 2012;1:166-75.

[24] Adeoye IS, Oladeinde O, Adeoye J. An assessment of asymptomatic bacteriuria among women with vesico- vaginal fistula in SouthEastern,Nigeria.Nepal J of Epidemiology, 2010; 1(2): 64 -69.

[25] Wondimeneh Y, Muluye D, Alemu A, Atinafu A, Yitayew, G, Gebrecherkos T, Alemu AG, Damtie D, Ferede G. Urinary tract infection among obstetric fistula patients at Gondar University Hospital, Northwest Ethiopia. BMC Women's Health, 2014; 14:12.

[26] Rashmi M. Karigoudar, Mahesh H. Karigoudar, Sanjay M. Wavare and 
Smita S. Mangalgi. Detection of Biofilm among uropathogenic Escherichia coli and its correlation with antibiotic resistance pattern, J Lab Physicians, 2019; 11(1) 17-22.

[27] Sara M. Soto and Octavio O. Franco. Importance of Biofilms in urinary tract infections, New therapeutic approaches, 2014; 22(6) 55-74.

[28] Ponnusamy P, Natarajan V, Sevanam M. In vitro Biofilm formation by uropathogenic Escherichia coli and their antimicrobial susceptibility pattern, Asian Pac, j. Trop Med; 2012; 5: 210-3.

[29] Soto SM, Smithson A,Horcajada JP, Maritinez JA, Mensa JP and Vila J. Implication of Biofilm formation in the persistence of urinary tract infection caused by uropathogenic Escherichia coli, Clin Microbiol Infect, 2006;12: 1034-6.

[30] Clinical and laboratory standards institute, CLSI Document M100 S24, Vol. 33 Wayne, PA, USA; Clinical and laboratory standards institute; 2014, Performance standards for Antimicrobial susceptibility testing, Twenty-fourth informational supplement.

[31] Hoiby N, Bjarnsholt T, Givskov M, Molin S, Ciofu O. Antibiotic resistance of bacterial biofilms, International $J$ of Antimicrobial Agents, 2010; 35(4): 322-332. 